\title{
Dual effects of human neutrophil peptides in a mouse model of pneumonia and ventilator-induced lung injury
}

Junbo Zheng ${ }^{1 \dagger}$, Yongbo Huang ${ }^{2 \dagger}$, Diana Islam ${ }^{3}$, Xiao-Yan Wen ${ }^{3}$, Sulong $\mathrm{Wu}^{2}$, Catherine Streutker ${ }^{3}$, Alice Luo ${ }^{3}$, Manshu Li $i^{2,3}$, Julie Khang ${ }^{3}$, Bing Han ${ }^{3}$, Nanshan Zhong ${ }^{2}$, Yimin Li ${ }^{2^{*}}$, Kaijiang Yu ${ }^{4^{*}}$ and Haibo Zhang ${ }^{2,3,5^{*}}$

\begin{abstract}
Background: Pneumonia is a major cause of high morbidity and mortality in critically illness, and frequently requires support with mechanical ventilation. The latter can lead to ventilator-induced lung injury characterized by neutrophil infiltration. The cationic human neutrophil peptides (HNP) stored in neutrophils can kill microorganisms, but excessive amount of HNP released during phagocytosis may contribute to inflammatory responses and worsen lung injury. Based on our previous work, we hypothesized that blocking the cell surface purinergic receptor P2Y, will attenuate the HNP-induced inflammatory responses while maintaining their antimicrobial activity in pneumonia followed by mechanical ventilation.
\end{abstract}

Methods: Plasma HNP levels were measured in patients with pneumonia who received mechanical ventilation and in healthy volunteers. FVB littermate control and HNP transgenic $\left(H N P^{+}\right)$mice were randomized to receive $P$. aeruginosa intranasally. The $\mathrm{P}_{2} \mathrm{Y}_{6}$ antagonist (MRS2578) or vehicle control was given after $P$. aeruginosa instillation. Additional mice underwent mechanical ventilation at either low pressure (LP) or high pressure (HP) ventilation $48 \mathrm{~h}$ after pneumonia, and were observed for $24 \mathrm{~h}$.

Results: Plasma HNP concentration increased in patients with pneumonia as compared to healthy subjects. The bacterial counts in the bronchoalveolar lavage fluid (BALF) were lower in $\mathrm{HNP}^{+}$mice than in FVB mice $72 \mathrm{~h}$ after $P$. aeruginosa instillation. However, upon receiving HP ventilation, $\mathrm{HNP}^{+}$mice had higher levels of cytokines and chemokines in BALF than FVB mice. These inflammatory responses were attenuated by the treatment with MRS2578 that did not affect the microbial effects of HNP.

Conclusions: HNP exerted dual effects by exhibiting antimicrobial activity in pneumonia alone condition while enhancing inflammatory responses in pneumonia followed by HP mechanical ventilation. Blocking $\mathrm{P}_{2} \mathrm{Y}_{6}$ can attenuate the inflammation without affecting the antibacterial property of HNP. The $\mathrm{P}_{2} \mathrm{Y}_{6}$ receptor may be a novel therapeutic target in attenuation of the leukocyte-mediated excessive host responses in inflammatory lung diseases.

Keywords: a-Defensins, Neutrophil, P2Y 6 purinergic receptor, Bacteria clearance, Inflammation, Ventilator-induced lung injury

\footnotetext{
*Correspondence: dryiminli@vip.163.com; drkaijiang@163.com;

zhangh@smh.ca

†unbo Zheng and Yongbo Huang contributed equally to this work.

${ }^{2}$ The State Key Laboratory of Respiratory Disease, The First Affiliated Hospital

of Guangzhou Medical University, Guangzhou 510000, Guangdong, China

${ }^{4}$ Department of Critical Care Medicine, The Third Affiliated Hospital of Harbin

Medical University, Harbin 150000, Heilongjiang, China

Full list of author information is available at the end of the article
}

(c) The Author(s). 2018 Open Access This article is distributed under the terms of the Creative Commons Attribution 4.0 International License (http://creativecommons.org/licenses/by/4.0/), which permits unrestricted use, distribution, and reproduction in any medium, provided you give appropriate credit to the original author(s) and the source, provide a link to the Creative Commons license, and indicate if changes were made. The Creative Commons Public Domain Dedication waiver (http://creativecommons.org/publicdomain/zero/1.0/) applies to the data made available in this article, unless otherwise stated. 


\section{Background}

Bacterial pneumonia is a leading cause of acute respiratory distress syndrome (ARDS) and sepsis contributing to high mortality in the intensive care unit (ICU) [1-3]. During the onset of pneumonia neutrophils are recruited into the infected site and serve as the first line of innate host defense. In patients with pneumonia-associated respiratory dysfunction, mechanical ventilation is an essential supportive approach $[4,5]$, however, it can lead to ventilator-induced lung injury (VILI). VILI is characterized by neutrophil sequestration that is associated with uncontrolled inflammatory responses [6]. The designate biological consequences of neutrophil infiltration are two folds: 1) Eliminate the pathogens through phagocytosis, and 2) Generate inflammatory responses by production of oxygen radicals, proteolytic enzymes and release of antimicrobial peptides [7].

Pneumonia, ARDS and VILI shares a typical feature of neutrophil infiltration [8-10] acquired for phagocytosis of microbial intruders. Upon completion of phagocytosis the professional phagocytes release granules' constituents that are strongly anti-microbial but may also cause damage by destructing surrounding tissue. Human neutrophils peptides (HNP) are the most abundant proteins in the azurophilic granules of neutrophils [11], and have been shown to induce inflammatory responses in human lung epithelial and endothelial cells [12-16] and to cause lung injury in mouse models $[14,17]$ in addition to the microbicidal properties [18]. It is important for one to understand the exact role of HNP in the complex infectious and inflammatory conditions in order to maintain the protective effects while eliminating the unwanted immunological consequences.

HNP, also called $\alpha$-defensins, are a family of cationic antimicrobial peptides against a broad arrays of pathogens [18]. HNP are synthesized during the promyelocyte stage of neutrophil maturation in bone marrow, and are transported to azurophil granules thus the amount of HNP stored in each granule remains unchanged in mature neutrophils [19], and HNP content is correlated with the number of leukocyte count [20]. Plasma levels of HNP released from neutrophils are under $50 \mathrm{ng} / \mathrm{mL}$ in healthy volunteers, but increase up to 4 folds in patients with bacterial infection [21]. HNP concentrations in bronchoalveolar lavage fluid (BALF) can be as high as 50 -fold greater in ARDS patients than in healthy volunteers, and are correlated with IL-8 levels in BALF [20]. In patients with cystic fibrosis and mouse model of lung injury, we have previously demonstrated that HNP act on neutrophils and lung epithelium through the purinergic $\mathrm{P}_{2} \mathrm{Y}_{6}$ receptor [16] resulting in inflammatory responses.

In this study, we employed $\mathrm{HNP}^{+}$transgenic mice to specifically examine the effects of HNP in the models of pneumonia and VILI to reproduce human clinical situations in which large amount of HNP is released [20, 21]. We tested the hypothesis that HNP are protective in pneumonia conditions but are harmful when excessively released in inflammatory conditions when inadequate mechanical ventilation is applied. Blocking $\mathrm{P}_{2} \mathrm{Y}_{6}$ receptor may attenuate the HNP-induced inflammatory responses without interrupting their antimicrobial activity, serving as a novel therapeutic approach in inflammatory lung diseases.

\section{Methods \\ Plasma collection from pneumonia patients and healthy volunteers}

The study was approved by the First Affiliated Hospital of Guangzhou Medical University Institutional Review Board (REC\#201311), and written informed consent was obtained from all subjects. Patients with pneumonia admitted to the ICU were consecutively enrolled during October 2012-May 2014. Pneumonia diagnosis was based on clinical features (i.e., fever, dyspnea, increased or purulent secretions, dry and moist rales), chest infiltrates and positive sputum culture [22]. Exclusion criteria were those patients who received chemotherapy within 8 weeks prior to ICU admission. A total of 43 patients ( $>18$ years) with pneumonia who underwent invasive mechanical ventilation within $24 \mathrm{~h}$ of admission were included (Table 1 ). Age-matched healthy volunteers $(n=43)$ were recruited at physical check-up clinic serving as a control group. Blood samples were collected in EDTA tubes.

\section{HNP endocytosis and IL-8 assays}

Human lung epithelial cells (BEAS-2B, ATCC, Manassas, VA) were seeded at $2.5 \times 10^{5}$ cells/slide in chamber slides (Nunc, Naperville, IL), incubated for $30 \mathrm{~min}$ at $37{ }^{\circ} \mathrm{C}$ with FITC-labeled HNP $(10 \mu \mathrm{g} / \mathrm{mL})$. In additional chamber slides, BEAS-2B cells were treated for $30 \mathrm{~min}$ with $10 \mu \mathrm{M}$ of reactive blue (a purinoceptor (P2Y) antagonist) [23], or suramin (a blocker for receptor-mediated endocytosis), prior to HNP stimulation $(100 \mu \mathrm{g} / \mathrm{mL})$. The cells were then fixed, stained with rhodamine-phalloidin (ThermoFisher Scientific), a high-affinity F-actin probe conjugated to the red-orange fluorescent dye for F-actin, and mounted for visualization.

In separate experiments, BEAS-2B cells or human monocytes (THP-1, ATCC, Manassas, VA) were treated with $10 \mu \mathrm{M}$ of reactive blue or suramin $30 \mathrm{~min}$ before HNP stimulation $(100 \mu \mathrm{g} / \mathrm{mL})$ for $8 \mathrm{~h}$. The supernatants were collected for measurement of IL-8 (MyBioSource, San Diego, CA).

\section{$P$. aeruginosa culture}

P. aeruginosa strain (ATCC 27853, Manassas, VA) was incubated overnight at $37{ }^{\circ} \mathrm{C}$ on $5 \%$ sheep blood agar plates, and colonies were picked and grown overnight in 
Table 1 Characteristics of patients with pneumonia and healthy subjects

\begin{tabular}{|c|c|c|}
\hline & $\begin{array}{l}\text { Pneumonia } \\
(N=43)\end{array}$ & $\begin{array}{l}\text { Healthy } \\
(N=43)\end{array}$ \\
\hline Age (year) & $63.8 \pm 2.4$ & $63.3 \pm 0.7$ \\
\hline Female/Male & $12 / 31$ & $19 / 24$ \\
\hline APACHE $\|$ & $18.1 \pm 1.0$ & \\
\hline \multicolumn{3}{|l|}{ MV mode } \\
\hline IPPV & $44 \%(N=19)$ & \\
\hline SIMV & $26 \%(N=11)$ & \\
\hline $\mathrm{A} / \mathrm{C}$ & $14 \%(N=6)$ & \\
\hline Others & $16 \%(N=7)$ & \\
\hline $\mathrm{VT}(\mathrm{mL})$ & $425.9 \pm 6.9$ & \\
\hline PEEP $\left(\mathrm{cmH}_{2} \mathrm{O}\right)$ & $6.9 \pm 0.5$ & \\
\hline $\mathrm{PaO}_{2} / \mathrm{FiO}_{2}$ & $168.4 \pm 10.3$ & \\
\hline WBC counts $\left(\times 10^{9} / L\right)$ & $14.3 \pm 1.2^{*}$ & $7.9 \pm 0.3$ \\
\hline Neutrophil counts $\left(\times 10^{9} / \mathrm{L}\right)$ & $12.8 \pm 1.1^{*}$ & $6.1 \pm 0.3$ \\
\hline Hemoglobin (g/L) & $94.9 \pm 2.8^{*}$ & $142.5 \pm 1.8$ \\
\hline PLT counts $\left(\times 10^{9} / \mathrm{L}\right)$ & $209.6 \pm 25.4^{*}$ & $253.9 \pm 6.8$ \\
\hline Creatinine $(\mu \mathrm{mol} / \mathrm{L})$ & $113.8 \pm 15.0$ & \\
\hline $\mathrm{PCT}(\mu \mathrm{g} / \mathrm{L})$ & $17.0 \pm 6.8$ & \\
\hline HSCPR (mg/L) & $62.0 \pm 13.8$ & \\
\hline HNP concentration (ng/mL) & $215.9 \pm 39.1^{*}$ & $27.6 \pm 2.0$ \\
\hline \multicolumn{3}{|l|}{ Etiology of pneumonia } \\
\hline Acinetobacter baumannii & $35 \%(N=15)$ & \\
\hline Pseudomonas aeruginosa & $14 \%(N=6)$ & \\
\hline Stenotrophomonas maltophilia & $9 \%(N=4)$ & \\
\hline Staphylococcus haemolyticus & $7 \%(N=3)$ & \\
\hline Klebsiella pneumoniae & $7 \%(N=3)$ & \\
\hline Staphylococcus aureus & $7 \%(N=3)$ & \\
\hline Others & $21 \%(N=9)$ & \\
\hline \multicolumn{3}{|l|}{ Co-morbidities } \\
\hline COPD & $23 \%(N=10)$ & \\
\hline Hypertension & $35 \%(N=15)$ & \\
\hline Diabetes & $19 \%(N=8)$ & \\
\hline Renal failure & $14 \%(N=6)$ & \\
\hline Asthma & $2 \%(N=1)$ & \\
\hline Corticosteroid treatment & $37 \%(N=16)$ & \\
\hline ICU stay (days) & $28.9 \pm 3.5$ & \\
\hline ICU mortality (\%) & $33 \%$ & \\
\hline
\end{tabular}

Note: Data shown are mean \pm SEM. ${ }^{*} p<0.01$ vs. Healthy Abbreviations: $A / C$ assist/control, $A P A C H E$ acute physiology and chronic health evaluation, COPD chronic obstructive pulmonary disease, HNP human neutrophil peptides, HSCPR high-sensitivity C-reactive protein, ICU intensive care unit, IPPV intermittent positive pressure ventilation, $M V$ mechanical ventilation, $P C T$ procalcitonin, PEEP positive end expiratory pressure, $P L T$ platelet, SIMV synchronized intermittent mandatory ventilation, $V T$ tidal volume, WBC white blood cell
Tryptic Soy Broth (TSB, $5 \mathrm{~mL}$ per colony) at $37{ }^{\circ} \mathrm{C}$ at 170 rpm (MaxQTM 4500 orbital shaker, Thermo Scientific, Midland, ON, Canada). An overnight cultured bacteria was diluted into TSB, and incubated at a shaker for $2.5 \mathrm{~h}$. The bacteria were then centrifuged at $8000 \mathrm{rpm}$ (J2-MI Centrifuge, Beckman, USA) at $4{ }^{\circ} \mathrm{C}$. After washes with phosphate buffered saline (PBS), the bacterial pellets were resuspended in PBS to a desired density (i.e., an OD value of 0.24 corresponded to $1 \times 10^{8}$ colony formation units $(\mathrm{CFU}) / \mathrm{mL})$ determined by spectrophotometry, then the bacterial solution was instilled after 6 times dilutions. The bacterial density used for instillation and collected in the BALF was determined by serial dilutions culture. The culture solution was spread over TSB-agar plates for colony count after incubation overnight.

\section{Pneumonia and two-hit lung injury models}

The animal protocols were approved by the Animal Care Committee of St. Michael's Hospital. Male FVB mice (Jackson Laboratory, Bar Harbor, ME) served as background control and HNP transgenic $\left(\mathrm{HNP}^{+}\right)$mice [24] (St. Michael's Hospital, Toronto, ON) of 10-12 weeks old were anesthesized by intraperitoneal injection of ketamine hydrochloride $(50 \mathrm{mg} / \mathrm{kg})$ and xylazine $(10 \mathrm{mg} / \mathrm{kg})$, and randomized into either pneumonia (P. aeruginosa, P.a.) or vehicle control (PBS) groups. Pneumonia was induced by intranasal instillation of $60 \mu \mathrm{L}$ P. aeruginosa ( $10^{6} \mathrm{CFU} /$ mouse). This dose of $P$. aeruginosa was chosen based on a pilot study where $0.5 \times 10^{6}, 1 \times 10^{6}, 1.5 \times 10^{6}, 2 \times 10^{6}$ and $5 \times 10^{6} \mathrm{CFU} /$ mouse were used and $1 \times 10^{6} \mathrm{CFU} /$ mouse resulted in localized bacterial colonization without significant induction of cytokine responses. This would leave a signal gap with respect to cytokine responses and the severity of lung injury between the models of $P$. aeruginosa alone and two-hit injury of $P$. aeruginosa followed by mechanical ventilation.

Following $P$. aeruginosa instillation $48 \mathrm{~h}$ later, the mice were either assigned to breathe spontaneously or to receive orotracheal intubation for mechanical ventilation with either a relative protective ventilator strategy of low pressure (LP) ventilation at peak inspiratory pressure (PIP) $10 \mathrm{cmH}_{2} \mathrm{O}$, positive end-expiratory pressure (PEEP) $3 \mathrm{cmH}_{2} \mathrm{O}$, respiratory rate (RR) 120 breaths $/ \mathrm{min}$, or a relative injurious ventilator strategy of high pressure (HP) ventilation at PIP $22 \mathrm{cmH}_{2} \mathrm{O}$ (to cause overdistension), PEEP $0 \mathrm{cmH}_{2} \mathrm{O}$ (to cause atelectrauma), $\mathrm{RR}$ 70 breaths/min under $\mathrm{FiO}_{2}$ of 0.5 . Upon completion of 2 -h mechanical ventilation, mice were weaned and housed in animal facility for $24 \mathrm{~h}$.

\section{Administration of $\mathrm{P}_{2} \mathrm{Y}_{6}$ receptor antagonist}

MRS2578 (Sigma, St Louis, MO), a selective P2Y 6 receptor antagonist, was intraperitoneally injected at a 
dose of $4 \mu \mathrm{L} / \mathrm{g}$ body weight from a $10 \mu \mathrm{M}$ stock concentration $15 \mathrm{~min}$ after $P$. aeruginosa instillation. Since the half-life of MRS2578 is unknown, we chose to administer MRS2578 at $24 \mathrm{~h}$ and $48 \mathrm{~h}$ after the first dose, based on previous studies in mice where MRS2578 was effective for $24 \mathrm{~h}$ [25-27]. This dose was chosen based on our pilot study testing a dose-dependent response to $10 \mu \mathrm{M}$ or $20 \mu \mathrm{M}$ of MRS2578 in $\mathrm{HNP}^{+}$mice after established pneumonia. The triple doses of $10 \mu \mathrm{M}$ were able to decrease neutrophil infiltration without induction of toxicity. The same volume of $1 \%$ DMSO was used to serve as a vehicle control. Based on our pilot studies, we estimated the sample size of 7 /group would be sufficient in the present study by using PASS software assuming the expected standard deviation will be $20 \%$ of the mean between the groups, with 0.8 of power and $\alpha=$ 0.05 . Considering the sample size (i.e., $N=5-8$ mice/ group) being used in other relevant studies [14, 25-28], we finally chose to use 5 mice in PBS control groups, and 7 mice in pneumonia groups in both $\mathrm{FVB}$ and $\mathrm{HNP}^{+}$ strains.

\section{Bacterial count, total and differential cell count and albumin in BALF}

Upon completion of the study, tracheotomy was performed and a catheter (18G, BD Angiocath, Franklin Lakes, NJ) was inserted into the trachea. A microvessel clamp was used to clip the hilus of the left lung, the right lung was lavaged with three times of injection of $0.5 \mathrm{~mL}$ PBS from the catheter. The hilus of the right lung was then ligated and the right lung was excised. The clamp at the left lung was removed and paraformaldehyde was used to inflate the left lung from the catheter. The BALF was serially diluted and cultured for bacterial recovery and counting. The cell pellets were resuspended in PBS for cytospin analysis of cell differentiation. The albumin concentration in the BALF was measured with

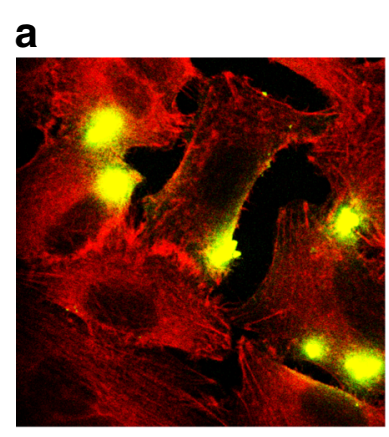

FITC-HNP

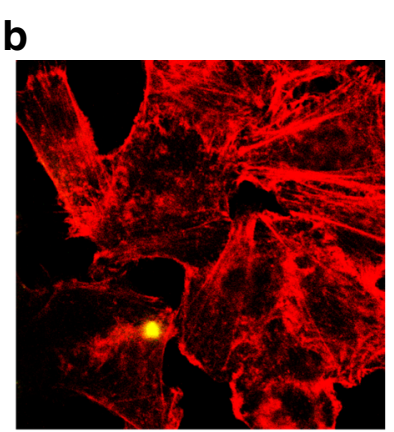

RB+FITC-HNP

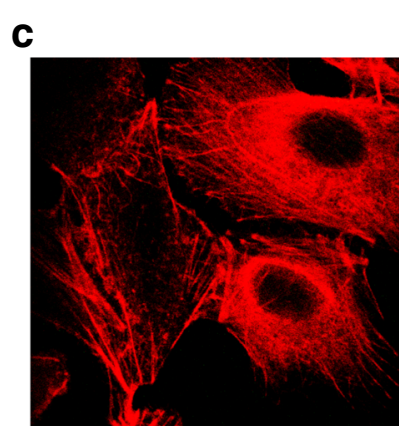

Suramin+FITC-HNP
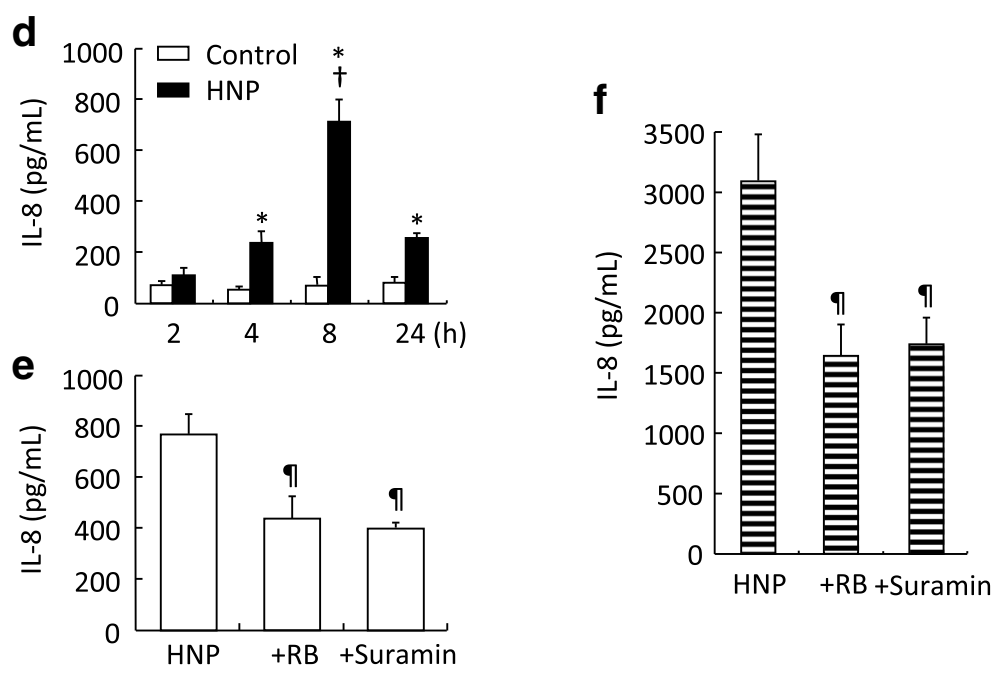

Fig. 1 HNP binding to BEAS-2B cells through P2Y receptor family. BEAS-2B cells were incubated with FITC-HNP for 30 min (a). HNP are labeled in green and F-actin in red. HNP binding was inhibited by addition of Reactive Blue (RB), or Suramin (b and c) 30 min prior to FITC-HNP. Effect of HNP on IL-8 production. HNP $(100 \mu \mathrm{g} / \mathrm{mL})$ induce $\mathrm{LL}-8$ production by BEAS-2B cells in a time-dependent manner $(\mathbf{d})$. RB $(10 \mu \mathrm{M})$ or suramin $(10 \mu \mathrm{M})$ added $30 \mathrm{~min}$ prior to HNP administration attenuated IL-8 production in BEAS-2B cells (e) and human THP-1 monocytes (f) at $8 \mathrm{~h}$. ${ }^{*} p<0.05$ vs. control group analyzed by Holm-Sidak test; $\uparrow p<0.05$ vs. HNP group at other three time points analyzed by Tukey's test; $\uparrow p<0.05$ vs. HNP group analyzed by one-way ANOVA, respectively 
a mouse albumin ELISA kit (Abcam, Toronto, Ontario, Canada).

\section{Measurement of HNP and cytokines/chemokines}

The HNP levels were determined as previously described [14]. Multiple mouse cytokines and chemokines (TNF- $\alpha$, IL-1 $\beta$, IL-6, IL-10, MCP-1 and KC) were measured in BALF by multiplex immunoassay using a Mouse ProcartaPlex Panel (e-Bioscience/Affymetrix, Santa Clara, CA).

\section{Lung histopathology}

The left lung was inflated and fixed with $4 \%$ paraformaldehyde and embedded in paraffin. Sections $(5 \mu \mathrm{m})$ were stained with hematoxylin and eosin (H\&E). Lung injury scores were assessed by a pathologist in a blinded fashion using a previously described scoring system based on 8 pathological features: alveolar distention, alveolar collapse, perivascular hemorrhage, perivascular edema, alveolar hemorrhage, alveolar edema, membranes formation and neutrophils infiltration. Each parameter was graded from 0 to 3 [29].

\section{Statistical analysis}

All data are presented as mean \pm SEM. The statistical analysis was performed using GraphPad Prism 6. For comparison between pneumonia patients and healthy control groups, the Mann-Whitney $U$ test was used. In vitro study, two-way ANOVA followed by Tukey's test or Holm-Sidak test was used for statistical comparisons to examine the effect of HNP on IL-8 production, and one-way ANOVA was used for comparisons between reactive blue, suramin and HNP group. Since multiple factors (i.e., mouse strains, bacteria, mechanical ventilation and MRS2578 treatment) were involved in vivo study, significant differences among multiple groups were examined using two-way ANOVA followed by Tukey's test or Holm-Sidak test. The multiple t-tests were also performed in some comparisons that tended to be significantly different after multiple comparisons for two-way ANOVA. A $p$ value $<0.05$ is considered statistically significant.

\section{Results}

Plasma HNP concentrations increased in patients with pneumonia

The demographic and clinical characteristics in patients with pneumonia and healthy subjects are shown in Table 1. There was no significant difference in age between pneumonia patients and healthy donors. Plasma HNP concentration as well as the peripheral white blood cell and neutrophil counts were significantly higher in patients with pneumonia than that in healthy subjects.

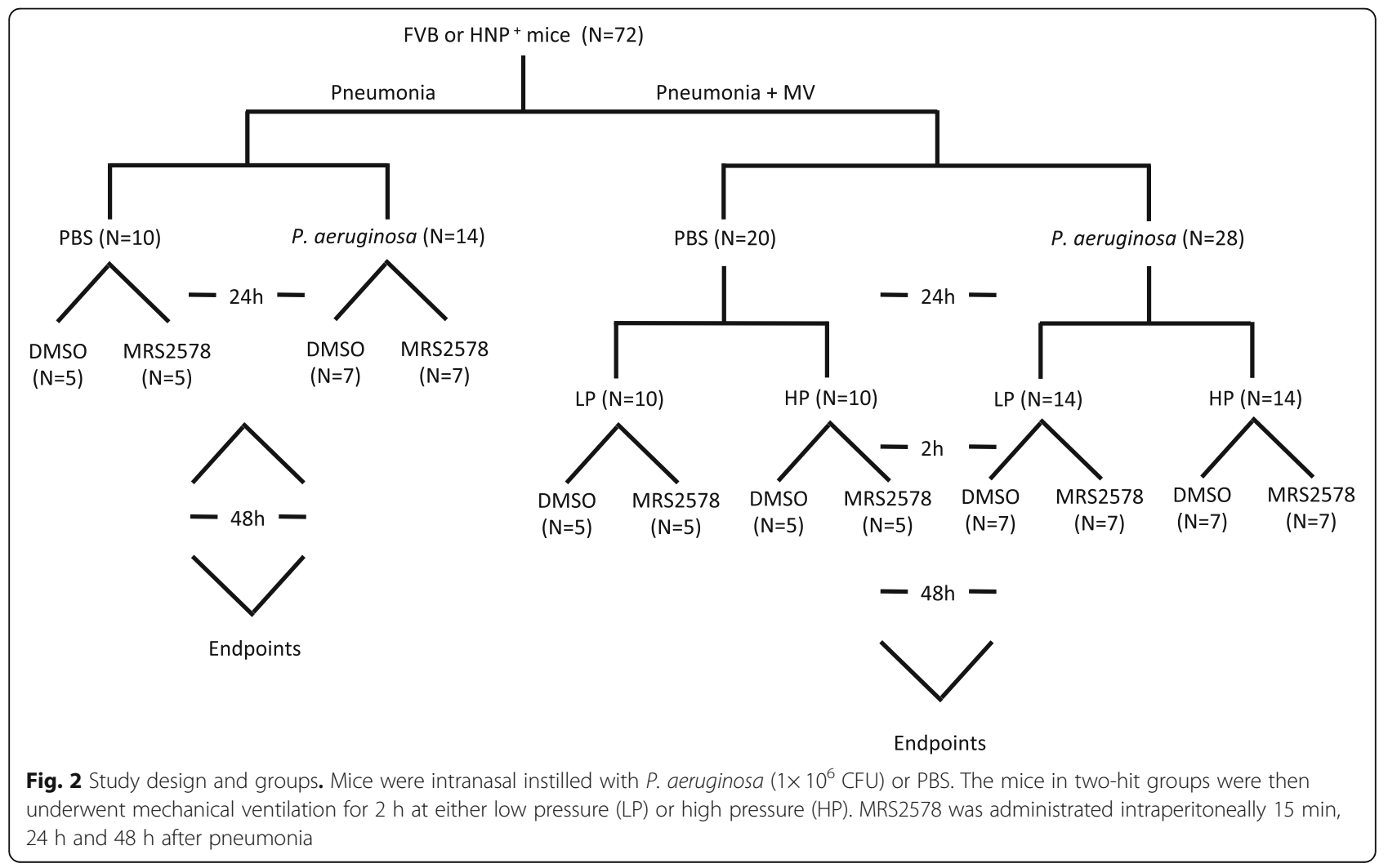


HNP endocytosis by lung epithelial cells

When human lung epithelial cells were incubated with FITC-labeled HNP, we observed HNP endocytosis associated with increased IL-8 production (Fig. 1a, d). Both HNP endocytosis and IL-8 production were inhibited by the use of reactive blue and suramin (Fig. 1a-e). The HNP-induced IL-8 production was also attenuated by pretreatment with reactive blue and suramin in the human THP-1 monocytes (Fig. 1f). These results provided us with strong rationale to test the use of $\mathrm{P}^{2} \mathrm{Y}_{6}$ inhibitor in vivo models (Fig. 2).

\section{Effects of MRS2578 in model of pneumonia alone}

HNP expression increased due to high neutrophil count in the $\mathrm{HNP}^{+}$mice despite the fact that there was a similar neutrophil recruitment in both FVB control mice (with no
HNP gene) and the $\mathrm{HNP}^{+}$(with HNP transgene) mice in response to $P$. aeruginosa instillation. The plasma HNP levels were higher in the $\mathrm{HNP}^{+}$mice especially in the pneumonia group (Fig. 3a, c). In the pneumonia alone conditions, the BALF bacterial counts were lower in the $\mathrm{HNP}^{+}$ mice than in the FVB mice (Fig. 3b), which was associated with neutrophil infiltration in the $\mathrm{HNP}^{+}$mice (Fig. 3c, d). The administration of MRS2578 had no effect in bacterial count (Fig. 3b), but decreased lung injury score in the $\mathrm{HNP}^{+}$mice and not in the FVB mice (Fig. 3d, f).

\section{Effects of MRS2578 in two-hit model of pneumonia followed by mechanical ventilation}

The inflammatory response was attenuated to a similar level following the treatment with MRS2578 at either

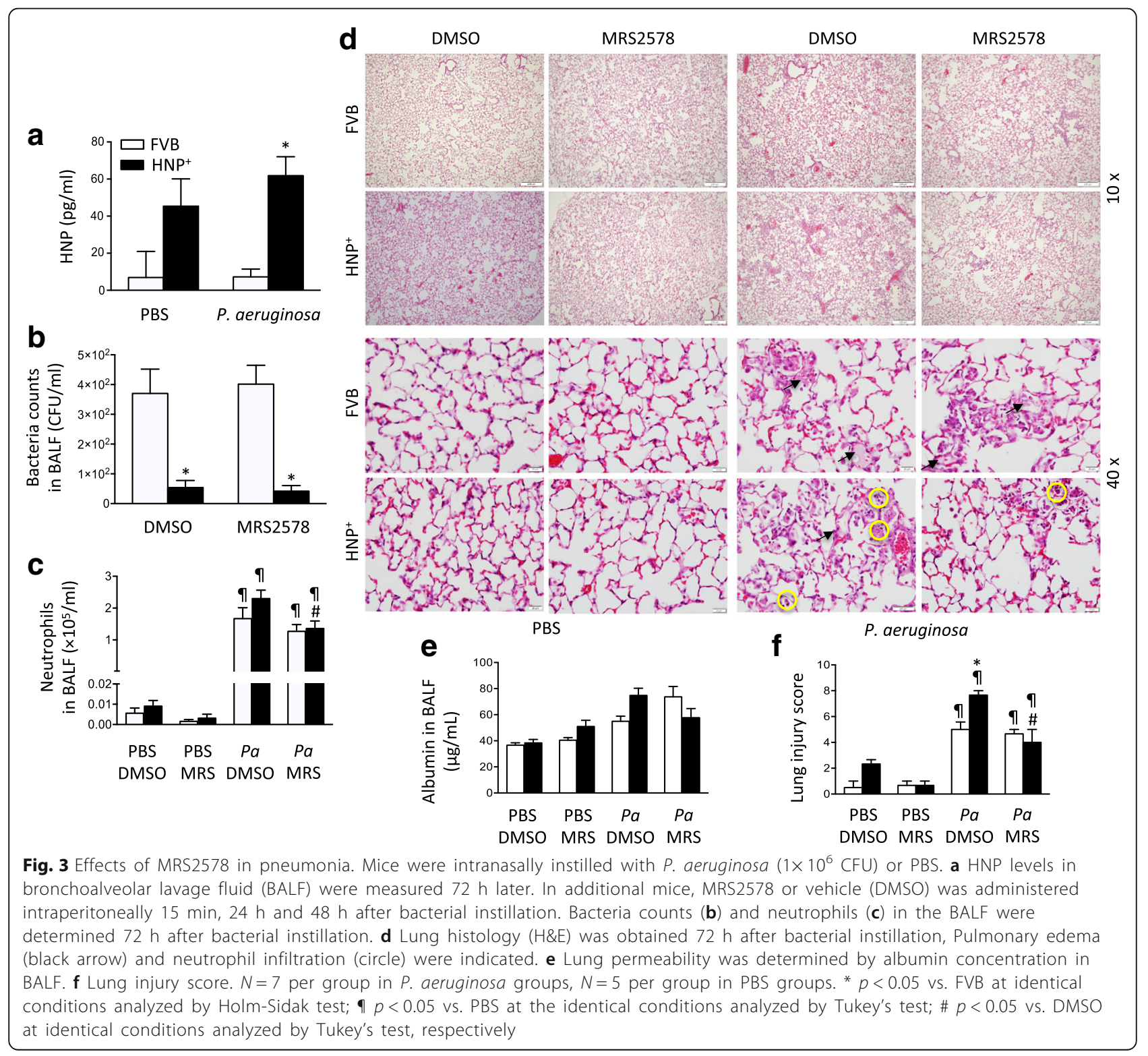


$10 \mu \mathrm{M}$ or $20 \mu \mathrm{M}$ in spontaneous breathing group and in the $\mathrm{HP}$ ventilated group after pneumonia in $\mathrm{HNP}^{+}$mice (Fig. 4a-c). Based on this observation, $10 \mu \mathrm{M}$ MRS2578 was used in the subsequent studies.

After $P$. aeriginosa instillation and mechanical ventilation, the bacterial counts remained lower in $\mathrm{HNP}^{+}$mice than in FVB mice, and the use of MRS2578 did not have any effect on bacterial count (Fig. 5a). The application of mechanical ventilation alone did not significantly affect neutrophil infiltration and albumin concentration in BALF (Fig. 5b, c). However, in the two-hit model an increase in inflammatory responses and lung permeability were observed especially in $\mathrm{HNP}^{+}$mice (Fig. 5b, c). The histological analysis showed a trend of increased lung injury score in the HP ventilation groups as compared to the LP ventilation groups but the difference did not reach statistically significance (Figs. $5 \mathrm{~d}$ and 6). A significant difference was reached in the two-hit injury model in $\mathrm{HNP}^{+}$mice (Figs. 5b-d and 6).

The levels of the pro-inflammatory cytokines/chemokines including TNF- $\alpha$, IL-1 $\beta$, IL-6, MCP- 1 and KC were significantly higher in the $\mathrm{HNP}^{+}$pneumonia mice under HP ventilation than other groups (Fig. 7a-e). The administration of MRS2578 resulted in an attenuation of leukocyte infiltration and lung injury (Figs. 5b-d and 6) as well as cytokine responses (Fig. 7).

\section{Discussion}

Our results demonstrated that HNP concentrations are significantly elevated in pneumonia patients with mechanical ventilation. The experimental studies revealed that HNP play a critical role in the host defense system against $P$. aeruginosa pneumonia, but can also contribute to excessive inflammatory responses in the VILI conditions.

The models of the $P$. aeruginosa induced-pneumonia used in the present study are highly relevant to clinical situations of ARDS [30, 31]. We observed that $\mathrm{HNP}^{+}$ mice had much lower bacterial count than FVB mice in pneumonia conditions. This observation is in agreement with the known mechanisms by which HNP exert antimicrobial properties by inducing membrane permeability a

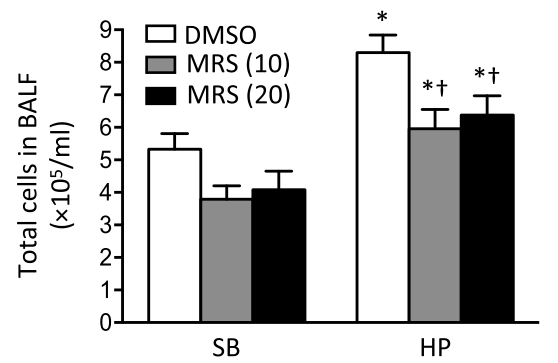

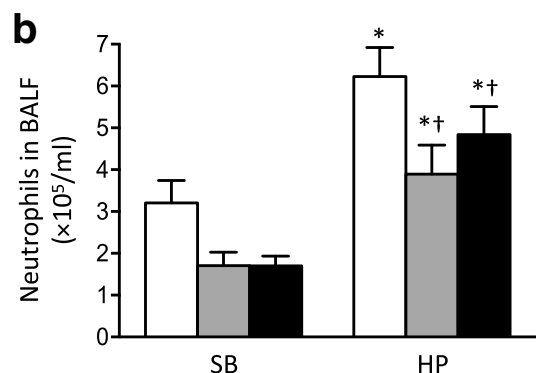

C

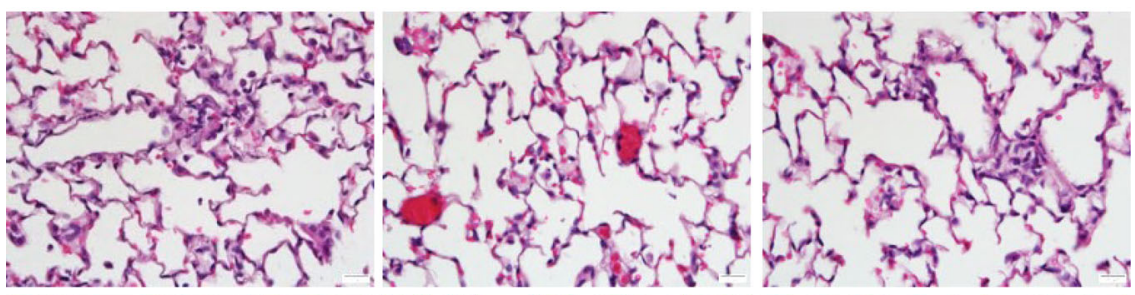

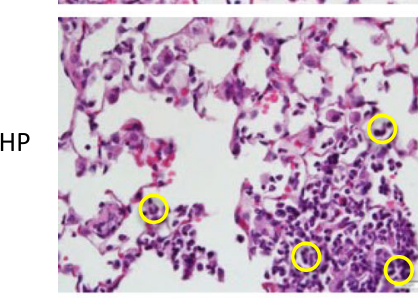

DMSO

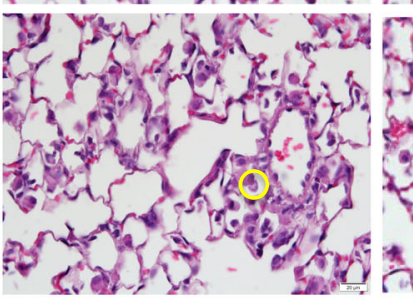

$\operatorname{MRS} 2578(10 \mu \mathrm{M})$

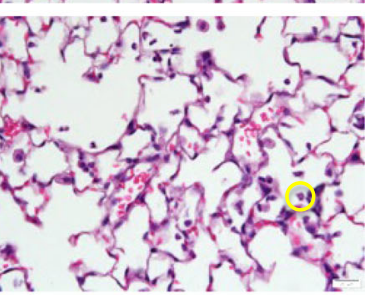

$\operatorname{MRS} 2578(20 \mu \mathrm{M})$

Fig. 4 Effects of MRS2578 in $\mathrm{HNP}^{+}$mice with pneumonia followed by mechanical ventilation. $\mathrm{HNP}^{+}$mice were intranasally instilled with $P$. aeruginosa $\left(1 \times 10^{6} \mathrm{CFU}\right)$ and then subjected to keep spontaneous breathing (SB) or mechanical ventilation with high pressure (HP) for $2 \mathrm{~h}$. MRS2578 at $10 \mu \mathrm{M}$ or $20 \mu \mathrm{M}$ was administrated intraperitoneally $15 \mathrm{~min}, 24 \mathrm{~h}$ and $48 \mathrm{~h}$ after pneumonia. Total cell counts (a) and neutrophil counts (b) in bronchoalveolar lavage fluid (BALF) were determined. c Lung histology (H\&E) was obtained $72 \mathrm{~h}$ after bacterial instillation. Neutrophil infiltration (circle) was indicated. $N=7$ per group. ${ }^{*} p<0.05$ vs. spontaneous breathing (SB) at identical conditions analyzed by Holm-Sidak test; $\dagger p<0.05$ vs. DMSO at identical conditions analyzed by Tukey's test, respectively 

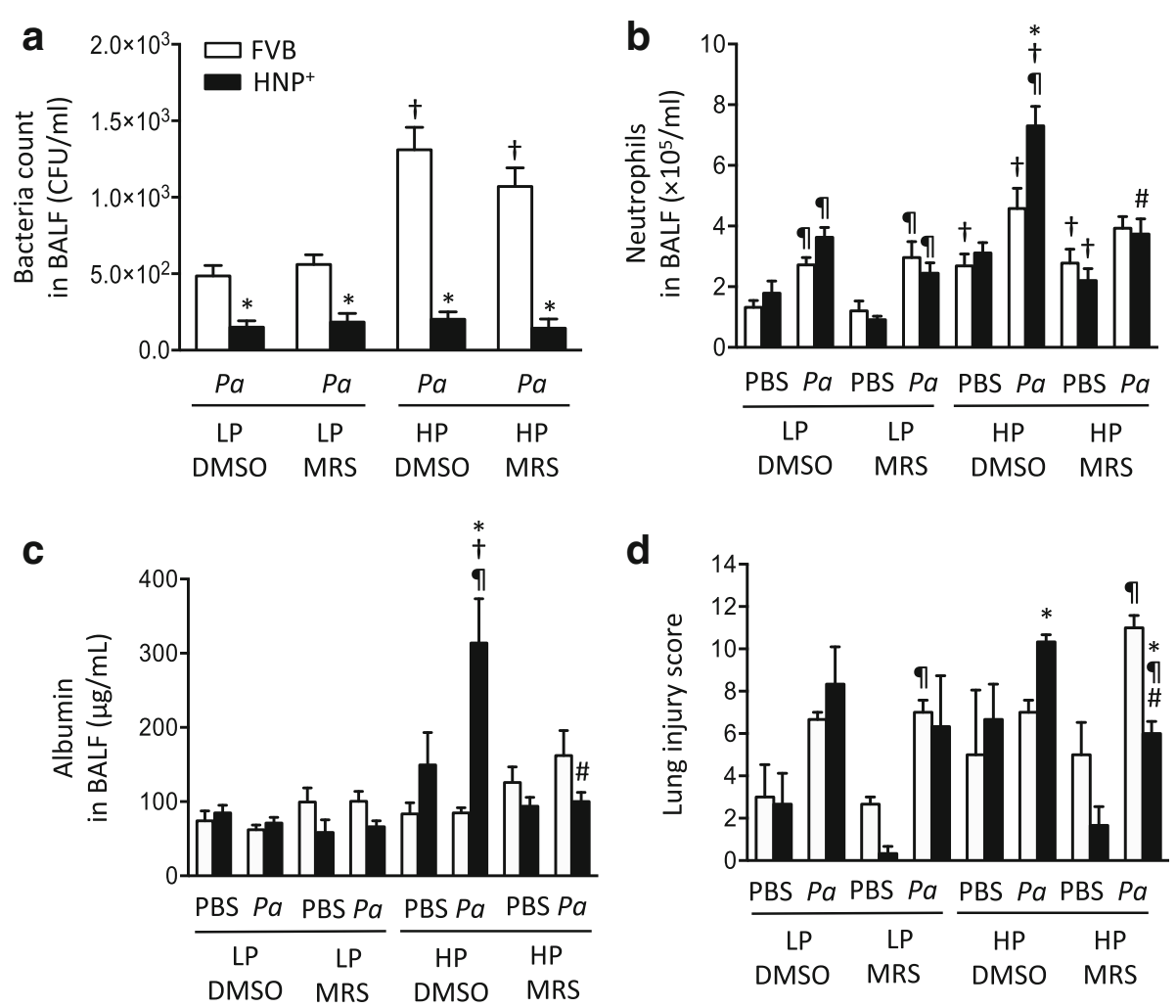

Fig. 5 Effects of MRS2578 in pneumonia followed by mechanical ventilation. Mice were intranasally instilled with P. aeruginosa $\left(1 \times 10^{6} \mathrm{CFU}\right)$ or PBS and received MRS2578 or vehicle (DMSO) $15 \mathrm{~min}, 24 \mathrm{~h}$ and $48 \mathrm{~h}$ after pneumonia, and then subjected to mechanical ventilation with either low (LP) or high (HP) pressure for 2 h. Bacteria counts (a) and neutrophil counts (b) in bronchoalveolar lavage fluid (BALF) were determined. c Lung permeability was determined by albumin concentration in BALF. $\mathbf{d}$ Lung injury score. $N=7$ per group in $P$. aeruginosa groups, $N=5$ per group in PBS groups. * $p<0.05$ vs. FVB at identical conditions analyzed by Holm-Sidak test; $\uparrow p<0.05$ vs. LP at identical conditions analyzed by multiple t tests; $9<0.05$ vs. PBS at the identical conditions analyzed by multiple t tests; \# $p<0.05$ vs. DMSO at identical conditions analyzed by Tukey's test, respectively

through the interaction between the positively charged HNP and the negatively charged microorganisms [32, 33], and also inhibiting cell wall synthesis [34].

Although FVB mice do not produce endogenous neutrophil peptides or HNP [35], they do show response to exogenous stimulation with HNP [17, 36, 37]. A previous study has reported greater lung damage by disrupting the capillary-epithelial barrier in $\mathrm{HNP}^{+}$mice than in wild-type mice after the $\mathrm{HCl}$-induced lung injury [28], our study was to examine the effects in a more clinical relevant conditions of pneumonia followed by mechanical ventilation. The protective effects of HNP seen in the pneumonia alone condition have turned into deleterious effects during an overwhelming inflammatory situation under two-hit injury. There are several potential explanations for this finding. Firstly, it has been shown that HNP can induce neutrophil influx into the lung by producing chemokines in lung epithelial cells $[12,13,17]$. Secondly, we have previously demonstrated that HNP at high concentrations interact with neutrophils resulting in decreased phagocytic capacity of neutrophils [14]. Finally, overproduction of reactive oxygen species by HNP [38] might have likely contributes to excessive inflammatory responses. HNP interact with host cells through $\mathrm{P}_{2} \mathrm{Y}_{6}$ receptor signaling, the use of $\mathrm{P} \mathrm{Y}_{6}$ antisense oligonucleotide resulted in attenuation of the HNP-induced IL-8 production in ex vivo human lung epithelial cells [16], which is independent of the cationic property. Our results demonstrate that the administration of MRS2578, a selective inhibitor of P2Y 6 receptor, was able to attenuate the HNP-mediated inflammatory responses (i.e. reduced levels of cytokines and chemokines) and lung injury during HP mechanical ventilation while maintaining the microbicidal activity. In the absence of HNP in FVB mice, the inflammatory responses persisted following pneumonia while administration of MRS2578 had no effect on the mechanical ventilation-induced inflammatory responses. These results further confirmed the involvement of $\mathrm{P}_{2} \mathrm{Y}_{6}$ receptor acts as a signal sensor for HNP [16] as well as a therapeutic target.

There are limitations in the present study. Our previous work focused on an in vitro study identifying $\mathrm{P}^{2} \mathrm{Y}_{6}$ 


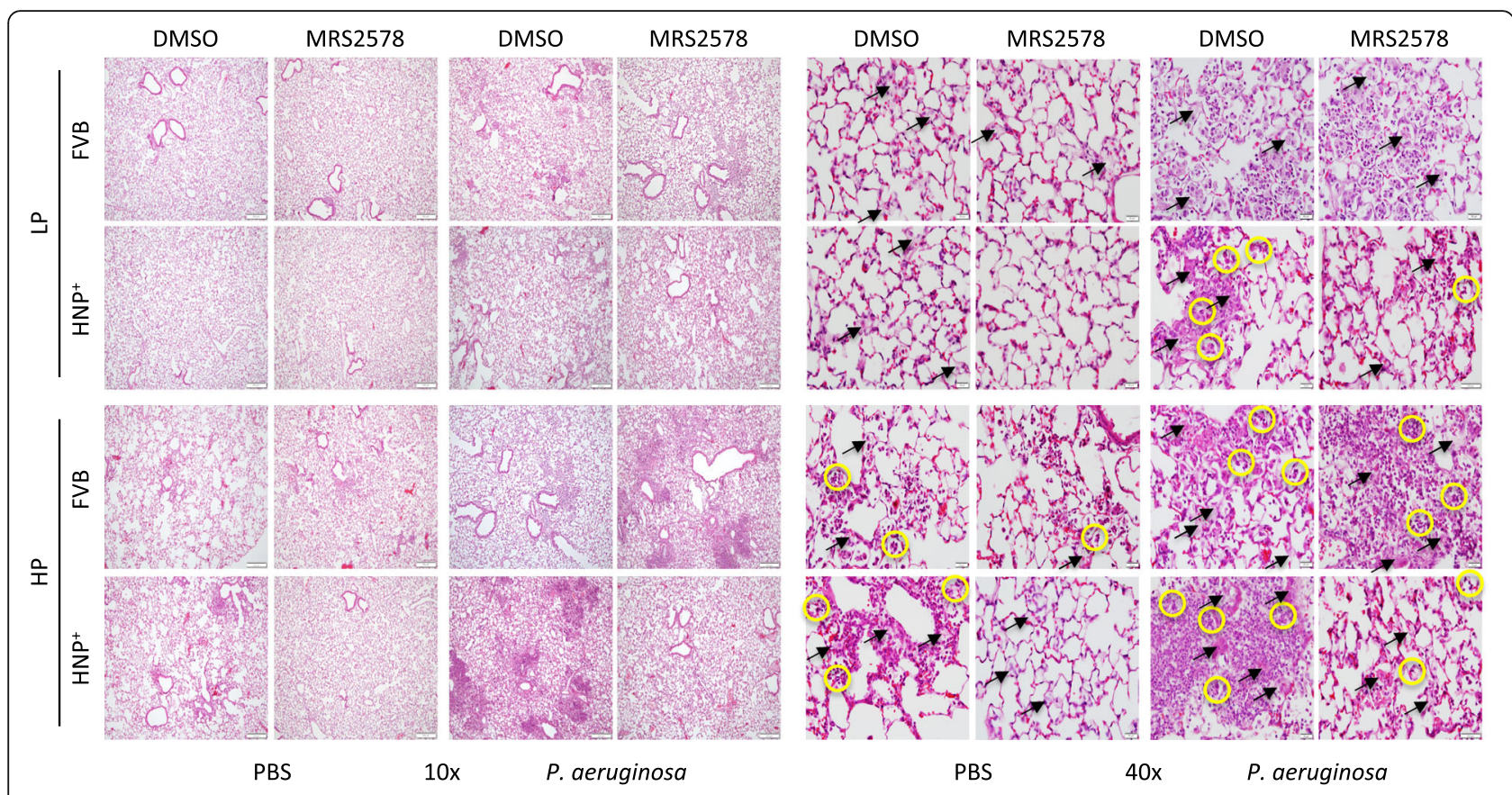

Fig. 6 Effects of MRS2578 on histological changes after two-hit lung injury. Mice were intranasally instilled with P. aeruginosa $\left(1 \times 10^{6} \mathrm{CFU}\right)$ or PBS and received MRS2578 or vehicle (DMSO) $15 \mathrm{~min}, 24 \mathrm{~h}$ and $48 \mathrm{~h}$ after pneumonia, and then subjected to mechanical ventilation with either low (LP) or high (HP) pressure for $2 \mathrm{~h}$. Lung histology (H\&E) was obtained $72 \mathrm{~h} \mathrm{~h}$ after pneumonia. Pulmonary edema (black arrow) and neutrophil infiltration (circle) were indicated

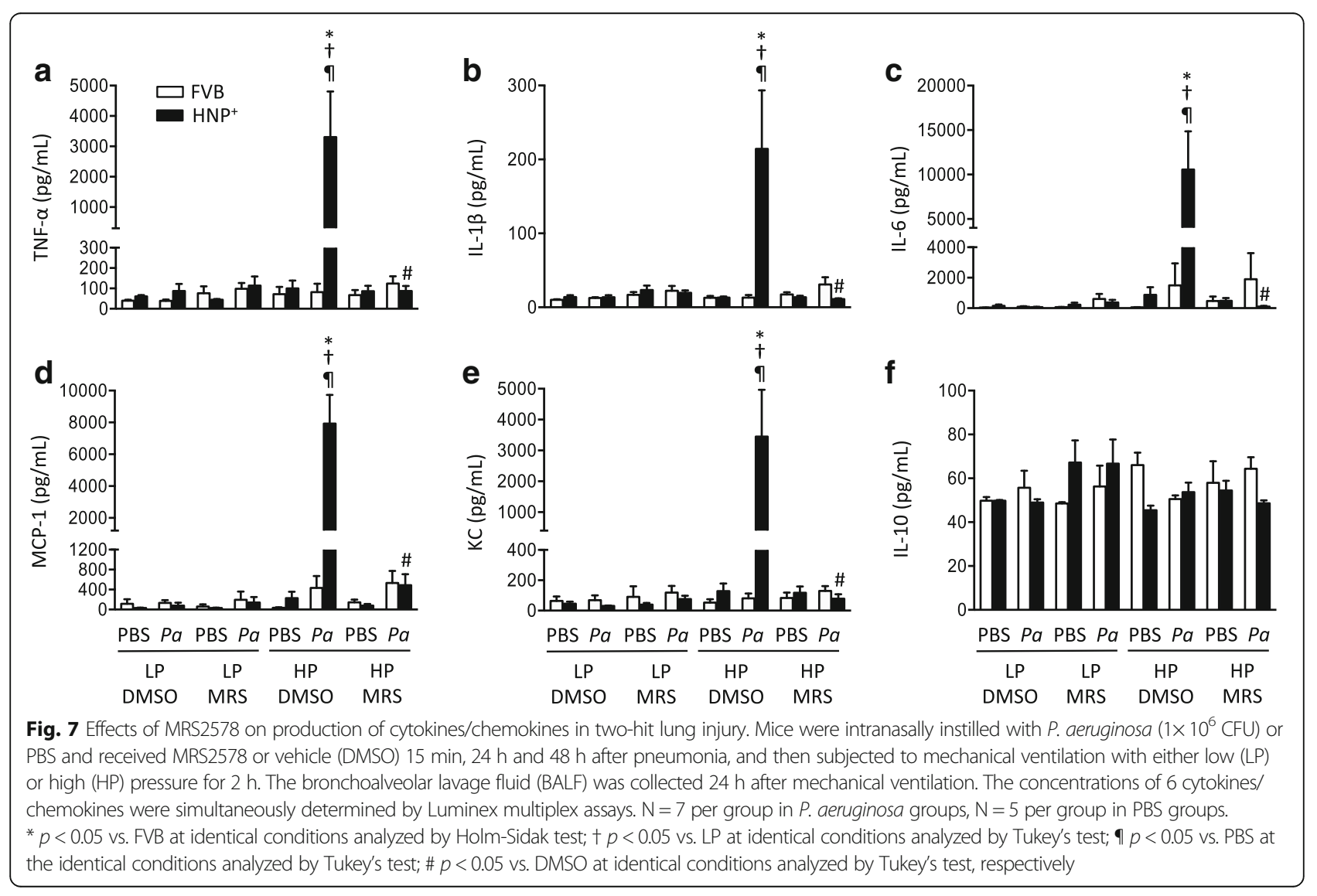


signaling in lung epithelial cells [16]. The present study extended the previous by testing the P2Y signal in human monocytes and the $\mathrm{P}_{2} \mathrm{Y}_{6}$ specific inhibitor in vivo two-hit model combining pneumonia and mechanical ventilation in order to understand the protective and detrimental effects of HNP in different inflammatory conditions. However, our experimental data does not allow one to suggest a critical concentration of HNP that would distinct protective effects from impairment and thus the exact dosage of $\mathrm{P}_{2} \mathrm{Y}_{6}$ blockade in clinical conditions. The $\mathrm{P}_{2} \mathrm{Y}_{6}$ receptor is broadly distributed in all organ tissues in human and mice $[39,40]$. Thus we did not examine the expression of $\mathrm{P}^{2} \mathrm{Y}_{6}$ receptor in our study. The scope of our study was to establish the linkage between $\mathrm{HNP}$ and $\mathrm{P}_{2} \mathrm{Y}_{6}$ receptor by application of MRS2578 in conditions of pneumonia and mechanical ventilation. Future studies maybe required to investigate the expression of $\mathrm{P}_{2} \mathrm{Y}_{6}$ receptor in different conditions such as pneumonia, mechanical ventilation and sepsis, respectively. It is worth noting that in addition to neutrophils, HNP can also be found in natural killer cells, $\mathrm{T}$ cells, and immature dendritic cells $[18,41,42]$, although it was unlikely the case in our acute models with dominant innate immunoresponse as opposed to a prolonged adaptive response involving immune cells other than neutrophils. Furthermore, we have previously reported that HNP mediated endothelial-monocyte interaction, foam cell formation and platelet activation [15]. The results obtained from our two-hit model using controlled titration of $P$. aeruginosa followed by mechanical ventilation may not be directly translated into all human situations in which bacterial phenotypes and invasion factors are variable. The present study opens a new avenue to conduct more in-depth clinical studies by including patients with ARDS due to non-infectious and patients with pneumonia who are not under mechanical ventilation.

\section{Conclusions}

In summary, our results suggested that blocking $\mathrm{P}^{2} \mathrm{Y}_{6}$ receptor signaling can attenuate the neutrophils, specifically, the HNP-mediated inflammatory responses without impairing the antimicrobial properties of HNP in the two-hit model of pneumonia followed by mechanical ventilation. Thus targeting the $\mathrm{P}_{2} \mathrm{Y}_{6}$ signaling may provide a novel therapeutic strategy to reserve the endogenous antimicrobial effects while attenuating the unwanted inflammatory consequence of HNP in inflammatory lung diseases.

\section{Abbreviations}

ARDS: acute respiratory distress syndrome; BALF: Bronchoalveolar lavage fluid; CFU: Colony formation units; H\&E: Hematoxylin and eosin; HNP: Human neutrophil peptides; HNP ${ }^{+}$: HNP transgenic; HP: High pressure; ICU: Intensive care unit; LP: Low pressure; P.a.: P. aeruginosa; PBS: Phosphate buffered saline;
PEEP: Positive end-expiratory pressure; PIP: Peak inspiratory pressure; RR: Respiratory rate; TSB: Tryptic Soy Broth; VILI: Ventilator-induced lung injury

\section{Acknowledgements}

Not applicable.

\section{Funding}

This study was supported by National Natural Science Foundation of China (Grant No. 81490534 to NZ and HZ; 81490530 to NZ and HZ; 81370177 to $\mathrm{HZ} ; 81361128003$ to NZ and YL; the Chief Scientist Project of Yangcheng Scholar in Guangzhou (Grant No. 1201541642) to HZ; and Canadian institute of Health Research (CIHR) to $\mathrm{HZ}$

Availability of data and materials

The datasets used and/or analysed during the current study are available from the corresponding author on reasonable request.

\section{Authors' contributions}

JZ, YH conducted the study, analyzed data and drafted the work. DI, SW, CS, $\mathrm{AL}, \mathrm{ML}, \mathrm{JK}$ and $\mathrm{BH}$ contributed to data acquisition, analysis and interpretation. NZ and KY interpreted the data. YL gathered clinical data and interpreted the data. $\mathrm{XW}$ and $\mathrm{HZ}$ guided study design and interpreted the data. JZ and $\mathrm{HZ}$ revised the manuscript. All authors read and approved the final manuscript.

\section{Ethics approval and consent to participate}

The clinical study was approved by the First Affiliated Hospital of Guangzhou Medical University Institutional Review Board (REC\#201311), and written informed consent was obtained from all subjects. The animal protocols were approved by the Animal Care Committee of St. Michael's Hospital.

\section{Consent for publication}

Not applicable.

\section{Competing interests}

The authors declare that they have no competing interests.

\section{Publisher's Note}

Springer Nature remains neutral with regard to jurisdictional claims in published maps and institutional affiliations.

\section{Author details}

${ }^{1}$ Department of Critical Care Medicine, The Second Affiliated Hospital of Harbin Medical University, Harbin 150000, Heilongjiang, China. ${ }^{2}$ The State Key Laboratory of Respiratory Disease, The First Affiliated Hospital of Guangzhou Medical University, Guangzhou 510000, Guangdong, China. ${ }^{3}$ Keenan Research Center for Biomedical Science of St. Michael's Hospital, Toronto, ON M5B 1W8, Canada. ${ }^{4}$ Department of Critical Care Medicine, The Third Affiliated Hospital of Harbin Medical University, Harbin 150000, Heilongjiang, China. ${ }^{5}$ Interdepartmental Division of Critical Care Medicine, Departments of Anesthesia and Physiology, University of Toronto, Toronto, ON M5B 1T8, Canada.

Received: 22 April 2018 Accepted: 20 August 2018

Published online: 29 September 2018

\section{References}

1. Bellani G, Laffey JG, Pham T, Fan E, Brochard L, Esteban A, et al. Epidemiology, patterns of care, and mortality for patients with acute respiratory distress syndrome in intensive care units in 50 countries. JAMA. 2016;315:788-800.

2. Vincent JL, Rello J, Marshall J, Silva E, Anzueto A, Martin CD, et al. International study of the prevalence and outcomes of infection in intensive care units. JAMA. 2009:302:2323-9.

3. Arthur LE, Kizor RS, Selim AG, van Driel ML, Seoane L. Antibiotics for ventilator-associated pneumonia. Cochrane Database Syst Rev. 2016; 10:CD004267

4. Restrepo MI, Mortensen EM, Velez JA, Frei C, Anzueto A. A comparative study of community-acquired pneumonia patients admitted to the ward and the ICU. Chest. 2008;133:610-7. 
5. Walden AP, Clarke GM, McKechnie S, Hutton P, Gordon AC, Rello J, et al. Patients with community acquired pneumonia admitted to European intensive care units: an epidemiological survey of the GenOSept cohort. Crit Care. 2014;18:R58.

6. Slutsky AS, Ranieri VM. Ventilator-induced lung injury. N Engl J Med. 2013;369:2126-36.

7. Mizgerd JP. Molecular mechanisms of neutrophil recruitment elicited by bacteria in the lungs. Semin Immunol. 2002;14:123-32.

8. Craig A, Mai J, Cai S, Jeyaseelan S. Neutrophil recruitment to the lungs during bacterial pneumonia. Infect Immun. 2009;77:568-75.

9. Williams AE, Chambers RC. The mercurial nature of neutrophils: still an enigma in ARDS? Am J Physiol Lung Cell Mol Physiol. 2014;306:L217-30.

10. Choudhury S, Wilson MR, Goddard ME, O'Dea KP, Takata M. Mechanisms of early pulmonary neutrophil sequestration in ventilator-induced lung injury in mice. Am J Physiol Lung Cell Mol Physiol. 2004;287:L902-10.

11. Gabay JE, Almeida RP. Antibiotic peptides and serine protease homologs in human polymorphonuclear leukocytes: defensins and azurocidin. Curr Opin Immunol. 1993;5:97-102

12. Vaschetto R, Grinstein J, Del Sorbo L, Khine AA, Voglis S, Tullis E, et al. Role of human neutrophil peptides in the initial interaction between lung epithelial cells and CD4+ lymphocytes. J Leukoc Biol. 2007:81:1022-31.

13. Syeda F, Liu HY, Tullis E, Liu M, Slutsky AS, Zhang H. Differential signaling mechanisms of HNP-induced IL-8 production in human lung epithelial cells and monocytes. J Cell Physiol. 2008;214:820-7.

14. Voglis S, Quinn K, Tullis E, Liu M, Henriques M, Zubrinich C, et al. Human neutrophil peptides and phagocytic deficiency in bronchiectatic lungs. Am J Respir Crit Care Med. 2009;180:159-66.

15. Quinn KL, Henriques M, Tabuchi A, Han B, Yang H, Cheng WE, et al. Human neutrophil peptides mediate endothelial-monocyte interaction, foam cell formation, and platelet activation. Arterioscler Thromb Vasc Biol. 2011;31:2070-9.

16. Khine AA, Del Sorbo L, Vaschetto R, Voglis S, Tullis E, Slutsky AS, et al. Human neutrophil peptides induce interleukin-8 production through the P2Y6 signaling pathway. Blood. 2006;107:2936-42.

17. Zhang H, Porro G, Orzech N, Mullen B, Liu M, Slutsky AS. Neutrophil defensins mediate acute inflammatory response and lung dysfunction in dose-related fashion. Am J Physiol Lung Cell Mol Physiol. 2001;280:L947-54.

18. Ganz T. Defensins: antimicrobial peptides of innate immunity. Nat Rev Immunol. 2003:3:710-20.

19. Valore EV, Ganz T. Posttranslational processing of defensins in immature human myeloid cells. Blood. 1992;79:1538-44.

20. Ashitani J, Mukae H, Arimura Y, Sano A, Tokojima M, Nakazato M. High concentrations of alpha-defensins in plasma and bronchoalveolar lavage fluid of patients with acute respiratory distress syndrome. Life Sci. 2004;75:1123-34.

21. Ihi T, Nakazato M, Mukae H, Matsukura S. Elevated concentrations of human neutrophil peptides in plasma, blood, and body fluids from patients with infections. Clin Infect Dis. 1997;25:1134-40.

22. American Thoracic S, Infectious Diseases Society of A. Guidelines for the management of adults with hospital-acquired, ventilator-associated, and healthcare-associated pneumonia. Am J Respir Crit Care Med. 2005;171:388-416.

23. Grobben B, Claes P, Roymans D, Esmans EL, Van Onckelen H, Slegers H. Ecto-nucleotide pyrophosphatase modulates the purinoceptor-mediated signal transduction and is inhibited by purinoceptor antagonists. $\mathrm{Br} \mathrm{J}$ Pharmacol. 2000;130:139-45.

24. Wu J, Han B, Fanelli V, Wen X, Huang Y, Luo A, et al. Distinctive Roles and Mechanisms of Human Neutrophil Peptides in Experimental Sepsis and Acute Respiratory Distress Syndrome. Crit Care Med. 2018. https://doi.org/ 10.1097/CCM.0000000000003265. [Epub ahead of print].

25. Zhang Z, Wang Z, Ren H, Yue M, Huang K, Gu H, et al. P2Y(6) agonist uridine $5^{\prime}$-diphosphate promotes host defense against bacterial infection via monocyte chemoattractant protein-1-mediated monocytes/macrophages recruitment. J Immunol. 2011;186:5376-87.

26. Vieira RP, Muller T, Grimm M, von Gernler V, Vetter B, Durk T, et al. Purinergic receptor type 6 contributes to airway inflammation and remodeling in experimental allergic airway inflammation. Am J Respir Crit Care Med. 2011;184:215-23.

27. Riegel AK, Faigle M, Zug S, Rosenberger P, Robaye B, Boeynaems JM, et al. Selective induction of endothelial P2Y6 nucleotide receptor promotes vascular inflammation. Blood. 2011;117:2548-55.

28. Bdeir K, Higazi AA, Kulikovskaya I, Christofidou-Solomidou M, Vinogradov SA, Allen TC, et al. Neutrophil alpha-defensins cause lung injury by disrupting the capillary-epithelial barrier. Am J Respir Crit Care Med. 2010;181:935-46.
29. Ko SC, Zhang H, Haitsma JJ, Cheng KC, Li CF, Slutsky AS. Effects of PEEP levels following repeated recruitment maneuvers on ventilator-induced lung injury. Acta Anaesthesiol Scand. 2008;52:514-21.

30. Sawa T, Corry DB, Gropper MA, Ohara M, Kurahashi K, Wiener-Kronish JP. IL10 improves lung injury and survival in Pseudomonas aeruginosa pneumonia. J Immunol. 1997;159:2858-66.

31. Junkins RD, Carrigan SO, Wu Z, Stadnyk AW, Cowley E, Issekutz T, et al. Mast cells protect against Pseudomonas aeruginosa-induced lung injury. Am J Pathol. 2014;184:2310-21.

32. Kagan BL, Selsted ME, Ganz T, Lehrer RI. Antimicrobial defensin peptides form voltage-dependent ion-permeable channels in planar lipid bilayer membranes. Proc Natl Acad Sci U S A. 1990;87:210-4.

33. Lehrer RI, Barton A, Daher KA, Harwig SS, Ganz T, Selsted ME. Interaction of human defensins with Escherichia coli. Mechanism of bactericidal activity. J Clin Invest. 1989:84:553-61.

34. de Leeuw E, Li C, Zeng P, Li C, Diepeveen-de Buin M, Lu WY, et al. Functional interaction of human neutrophil peptide-1 with the cell wall precursor lipid II. FEBS Lett. 2010;584:1543-8

35. Eisenhauer PB, Lehrer RI. Mouse neutrophils lack defensins. Infect Immun. 1992:60:3446-7.

36. Ayabe T, Satchell DP, Pesendorfer P, Tanabe H, Wilson CL, Hagen SJ, et al. Activation of Paneth cell alpha-defensins in mouse small intestine. J Biol Chem. 2002;277:5219-28.

37. Ouellette AJ, Lualdi JC. A novel mouse gene family coding for cationic, cysteine-rich peptides. Regulation in small intestine and cells of myeloid origin. J Biol Chem. 1990;265:9831-7.

38. Porro GA, Lee JH, de Azavedo J, Crandall I, Whitehead T, Tullis E, et al. Direct and indirect bacterial killing functions of neutrophil defensins in lung explants. Am J Physiol Lung Cell Mol Physiol. 2001;281:L1240-7.

39. von Kugelgen I, Wetter A. Molecular pharmacology of P2Y-receptors. Naunyn Schmiedeberg's Arch Pharmacol. 2000;362:310-23.

40. Communi D, Paindavoine P, Place GA, Parmentier M, Boeynaems JM. Expression of $\mathrm{P} 2 \mathrm{Y}$ receptors in cell lines derived from the human lung. Br J Pharmacol. 1999;127:562-8.

41. Agerberth B, Charo J, Werr J, Olsson B, Idali F, Lindbom L, et al. The human antimicrobial and chemotactic peptides LL-37 and alphadefensins are expressed by specific lymphocyte and monocyte populations. Blood. 2000;96:3086-93.

42. Rodriguez-Garcia M, Oliva H, Climent N, Garcia F, Gatell JM, Gallart T. Human immature monocyte-derived dendritic cells produce and secrete alphadefensins 1-3. J Leukoc Biol. 2007:82:1143-6.

Ready to submit your research? Choose BMC and benefit from:

- fast, convenient online submission

- thorough peer review by experienced researchers in your field

- rapid publication on acceptance

- support for research data, including large and complex data types

- gold Open Access which fosters wider collaboration and increased citations

- maximum visibility for your research: over $100 \mathrm{M}$ website views per year

At $\mathrm{BMC}$, research is always in progress.

Learn more biomedcentral.com/submissions 